\title{
Sammenliknende effektforskning
}

\author{
Hva bør comparative effectiveness research hete på norsk? Vi foreslår sammenliknende effektforskning.
}

Comparative effectiveness research fikk mye oppmerksomhet i 2009, da 1,1 milliarder dollar ble delt ut til slik forskning i USA som en del av president Obamas stimuleringspakke for den amerikanske økonomien (1). Denne typen studier innebærer ingen ny tankegang i medisinsk forskning, men definerer et viktig opplegg for studier der to eller flere metoder sammenliknes direkte (2).

Det finnes mange metoder for diagnostikk og behandling, men få er testet ut mot hverandre. I dag brukes ofte flere behandlinger eller diagnostiske metoder for samme tilstand, uten at man vet hvilken som er den beste. Direkte sammenlikninger, f.eks. mellom to eller flere blodtrykksmedisiner, er mangelvare (1). Et annet kjennetegn ved denne type forskning er at den gjennomføres under forhold som mest mulig etterlikner vanlig klinisk praksis, f.eks. i store pasientpopulasjoner, uten de strenge eksklusjonskriteriene som ofte finnes i placebokontrollerte fase 3 -studier.

\section{Oversettelse}

På engelsk kalles denne forskningen comparative effectiveness research (CER). Metoden er blitt svært populær. Uttrykket gir 1900 treff på PubMed, så godt som alle fra etter 2007. Det er omtalt som et moteord (3).

I Tidsskriftet ble det forste gang brukt i 2011, men uten oversettelse (4). I en nyhetssak i 2012 ble «sammenliknende effektstudier» lansert (1), og dette gjenfinnes i enkelte dokumenter fra Norges forskningsråd og Nasjonalt kunnskapssenter for helsetjenesten på internett. Liknende oversettelse finnes også på svensk: «jämförande effektforskning» (5).

\section{Effekt eller effektivitet?}

På engelsk skiller man mellom effect, efficacy, effectiveness og efficiency. I norsk allmennspråk finnes ikke denne distinksjonen mellom effekt og effektivitet. I allmennordboken forklares effektivitet kort og godt som «det å være effektiv» (6). Heller ikke medisinske ordbøker gir noen veiledning.

Den effekten som måles ut fra standardiserte pasientmaterialer under kontrollerte forsøksbetingelser med kvalifisert helsepersonell og optimale ressurser betegnes ofte som behandlingens effekt (engelsk: efficacy). Først når behandlingen er forsøkt i vanlig klinisk praksis, får man erfaring med hvordan effektene er i det virkelige liv. Dette kalles gjerne behandlingens effekti-

Tabell 1 Engelske begreper med oversettelse og forklaring

$\begin{array}{lll}\text { Engelsk begrep } & \text { Norsk oversettelse } & \text { Forklaring } \\ \text { Efficacy } & \text { Effekt } & \text { Virksom i kliniske studier } \\ \text { Effectiveness } & \text { Effektivitet } & \text { Virker i klinisk praksis } \\ \text { Efficiency } & \text { Kostnadseffektivitet } & \text { Kostnad-nytte-verdi }\end{array}$

vitet (engelsk: effectiveness). Enda et effektbegrep brukes ofte, nemlig kostnadseffektivitet (engelsk: efficiency eller costeffectiveness), som kan oversettes som nytteverdien av behandlingen i forhold til kostnadene (7) (tab 1). Både studier av effekt og studier av effektivitet er viktige når man skal evaluere intervensjoner, men de har ulike formål og designer (8).

Hvordan skal de engelske effektbegrepene oversettes til norsk? Det er illustrerende at to offentlige utredninger fra 1997 ga ulike svar. I den ene brukte man engelsk terminologi, dels fordi «engelske termer ofte blir brukt i Norge» og dels fordi de tre engelske begrepene «alle blir oversatt til norsk med «effektivitet»»" (9). I den andre utredningen sto det at «vi på norsk bare bruker ett ord (effekt)» (10).

\section{Konklusjon}

Ettersom forkortelsen CER på engelsk står for «effectiveness research», burde det på norsk antakelig hete effektivitetsforskning for å få frem distinksjonen mellom efficacy (effekt) og effectiveness (effektivitet). På den måten ville det bli tydelig at det er effektivitetsstudier, ikke effektstudier, som er grunnlaget for denne forskningen.

Imidlertid brukes ofte effekt som fellesbegrep på norsk, og det ser ut til at effektforskning er i ferd med å bli etablert som oversettelse på både norsk og svensk. Dessuten ville effektivitet - dersom det ble valgt som oversettelse - lett bli tilbakeoversatt til et annet ord enn effectiveness.

Vi vil derfor foreslå at comparative effectiveness research kalles sammenliknende effektforskning på norsk.

\section{Erlend Hem}

erlend.hem@medisin.uio.no

Tidsskrift for Den norske legeforening

Petter Gjersvik

Institutt for klinisk medisin

Universitetet i Oslo
Michael Bretthauer

Institutt for helse og samfunn Universitetet i Oslo

Erlend Hem (f. 1970) er dr.med. og assisterende sjefredaktør i Tidsskriftet.

Michael Bretthauer (f. 1969) er leder av gruppe for klinisk effektforskning og professor ved Universitetet i Oslo.

Petter Gjersvik (f. 1952) er medisinsk redaktør i Tidsskriftet og førsteamanuensis ved Universitetet i Oslo.

Litteratur

1. Hem E. Ny måte å organisere screeningprogrammer på. Tidsskr Nor Legeforen 2012; 132: 1952.

2. Ashton CM. Wray NP. Comparative effectiveness research: evidence, medicine, and policy. New York: Oxford University Press, 2013.

3. El-Serag HB, Talwalkar J, Kim WR. Efficacy, effectiveness, and comparative effectiveness in liver disease. Hepatology 2010; 52: 403-7.

4. Feiring E. Hal beslutningstakeren. Tidsskr Nor Legeforen 2011; 131: 2196-8.

5. Hedlund F. Behandlingar ställs mot varandra i ny USA-forskning. Läkartidningen 2010; 107: 86-8. www.lakartidningen.se/07engine.php?articleld= 13579 (1.4.2014)

6. Effektivitet. I: Bokmålsordboka og Nynorskordboka. www.nob-ordbok.uio.no/perl/ordbok.cgi? OPP=effektivitet\&ordbok=begge (1.4.2014).

7. Effekt, effektivitet og kostnadseffektivitet. I:Norges offentlige utredninger. Alternativ medisin. NOU 1998: 21. www.regjeringen.no/nb/dep/hod/dok/ nouer/1998/nou-1998-21/13/4/1.html?id= $350874(1.4 .2014)$

8. Fritz JM, Cleland J. Effectiveness versus efficacy: more than a debate over language. J Orthop Sports Phys Ther 2003; 33: 163-5.

9. Bruk av økonomisk evaluering av legemidler. I: Norges offentlige utredninger. Piller, prioritering og politikk. NOU 1997: 7. www.regjeringen.no/ nb/dep/hod/dok/nouer/1997/nou-1997-7/5/ 7.html?id=343856 (1.4.2014)

10. Generaliserbarhet av vitenskapelige fors $ø k$ til klinisk praksis. I: Norges offentlige utredninger Prioritering på ny. NOU 1997: 18 www.regjeringen.no/nb/dep/hod/dok/nouer/1997/ nou-1997-18/9/7/4.html?id=345935 (1.4.2014).

Mottatt 2.4. 2014 og godkjent 7.4. 2014. Redaktør Marit Fjellhaug Nylund. 